\title{
INSL5 activates multiple signalling pathways and regulates GLP-1 secretion in NCI-H716 cells
}

\author{
Sheng Y Ang1, Bronwyn A Evans', Daniel P Poole1, Romke Bron', Jesse J DiCello1, Ross A D Bathgate2,3, \\ Martina Kocan², Dana S Hutchinson'1,4 and Roger J Summers ${ }^{1}$
}

1Drug Discovery Biology, Monash Institute of Pharmaceutical Sciences, Monash University, Parkville, Victoria, Australia ${ }^{2}$ The Florey Institute of Neuroscience and Mental Health, University of Melbourne, Parkville, Victoria, Australia ${ }^{3}$ Department of Biochemistry and Molecular Biology, University of Melbourne, Melbourne, Victoria, Australia ${ }^{4}$ Department of Pharmacology, Monash University, Clayton, Victoria, Australia

Correspondence should be addressed to S Y Ang: sheng.ang@monash.edu

\begin{abstract}
Insulin-like peptide 5 (INSL5) is a newly discovered gut hormone expressed in colonic enteroendocrine L-cells but little is known about its biological function. Here, we show using RT-qPCR and in situ hybridisation that Ins/5 mRNA is highly expressed in the mouse colonic mucosa, colocalised with proglucagon immunoreactivity. In comparison, mRNA for RXFP4 (the cognate receptor for INSL5) is expressed in various mouse tissues, including the intestinal tract. We show that the human enteroendocrine L-cell model $\mathrm{NCl}-\mathrm{H} 716$ cell line, and goblet-like colorectal cell lines SW1463 and LS513 endogenously express RXFP4. Stimulation of $\mathrm{NCl}-\mathrm{H} 716$ cells with INSL5 produced phosphorylation of ERK1/2 (Thr202/Tyr 204), AKT (Thr308 and Ser $\left.{ }^{473}\right)$ and S6RP (Ser235/236) and inhibited cAMP production but did not stimulate $\mathrm{Ca}^{2}+$ release. Acute INSL5 treatment had no effect on GLP-1 secretion mediated by carbachol or insulin, but modestly inhibited forskolinstimulated GLP-1 secretion in NCl-H716 cells. However, chronic INSL5 pre-treatment (18h) increased basal GLP-1 secretion and prevented the inhibitory effect of acute INSL5 administration. LS513 cells were found to be unresponsive to INSL5 despite expressing RXFP4. Another enteroendocrine L-cell model, mouse GLUTag cells did not express detectable levels of $R x f p 4$ and were unresponsive to INSL5. This study provides novel insights into possible autocrine/paracrine roles of INSL5 in the intestinal tract.
\end{abstract} Key Words

- INSL5

- RXFP4

- $\mathrm{NCl}-\mathrm{H} 716$

cell signalling

- GLP-1
Journal of Molecular Endocrinology (2018) 60, 213-224

\section{Introduction}

Insulin-like peptide 5 (INSL5) is a novel gastrointestinal (GI) hormone identified in colonic enteroendocrine L-cells along with glucagon-like peptide 1 (GLP-1) and peptide YY (PYY) (Grosse et al. 2014). The cognate receptor for INSL5 is the relaxin family peptide receptor 4 (RXFP4), a G protein-coupled receptor (GPCR) that couples to inhibitory $\mathrm{G} \alpha_{\mathrm{i} / \mathrm{o}}$ proteins (Liu et al. 2003, 2005) and activates a number of signalling pathways including phosphorylation of extracellular signal-regulated protein kinases 1 and 2 (ERK1/2), p38 mitogen-activated protein kinases (p38MAPK), protein kinase B (AKT) and S6 ribosomal protein (S6RP) (Ang et al. 2017). INSL5 activates RXFP4 but not the other relaxin family peptide receptors, RXFP1-3 (Halls et al. 2015). Previous transcriptomic and in situ hybridisation studies indicated that, like INSL5, RXFP4 is predominantly expressed in the GI tract i.e. colon and rectum (Yue et al. 2014, Uhlén et al. 2015), and is localised in regions that resemble the colonic 
submucosal and myenteric plexuses (Grosse et al. 2014). Furthermore, RXFP4 immunoreactivity has been reported in normal human mucosa and human neuroendocrine tumours (NETs) (Mashima et al. 2013, Thanasupawat et al. 2013) arising from enteroendocrine cells (Gunawardene et al. 2011).

The physiological role of INSL5 is still unclear, but it was reported to be an orexigenic peptide upregulated during periods of energy deprivation and suggested to act via the enteric nervous system (Grosse et al. 2014). Most notably, exogenous administration of INSL5 stimulated feeding in wild type but not in Rxfp4-deficient mice. In addition, INSL5 appears to play a role in glucose metabolism with suggested actions on pancreatic $\beta$-cell insulin secretion (Burnicka-Turek et al. 2012, Luo et al. 2015) and hepatic glucose production (Lee et al. 2016). Furthermore, INSL5 reportedly stimulates ERK1/2 phosphorylation and promotes GLP-1 secretion in murine L-cell model GLUTag cell line (Luo et al. 2015), and RXFP4 is expressed in a number of mucin 2 (MUC2)-expressing, goblet-like human colorectal carcinoma cell lines (Mouradov et al. 2014). These findings suggest that INSL5 secreted from colonic L-cells is likely to act in an autocrine/paracrine manner on locally expressed RXFP4 to regulate gut functions such as peptide secretion from enteroendocrine cells and/or mucin secretion from goblet cells.

This study aims to elucidate the expression patterns of Insl5 and Rxfp 4 in various mouse tissues and investigate whether INSL5 can stimulate signalling in enteroendocrine L-cells and/or goblet cells using various cell culture models, which would provide evidence for an autocrine/ paracrine action of this gut hormone. We confirm that Insl5 is a product of L-cells in the colon while Rxfp 4 expression was detected at low levels in various tissues, including the intestinal tract. In addition, we report that the human enteroendocrine L-cell model NCI-H716 cell line, and goblet-like colorectal cell lines LS513 and SW1463, endogenously express RXFP4. Importantly, in NCI-H716 cells, INSL5 stimulates signalling and regulates GLP-1 secretion, suggesting a potential novel biological role for INSL5 in mediating L-cell function.

\section{Materials and methods}

\section{Mouse and tissue preparation}

129SvEv wild-type (WT) and RXFP4-deficient (Rxfp4-/-) mice were obtained from Dr Johannes Grosse (Takeda Cambridge Limited, Cambridge, UK) (Grosse et al. 2014). WT and Rxfp4-/- mice were genotyped before use
(Transnetyx, Cordova, TN, USA). C57BL/6J mice were obtained from the Monash Animal Research Platform. All mice were bred and maintained at the Monash University (Parkville) animal housing facility. Tissues for RT-qPCR and in situ hybridisation experiments were from C57BL/6J and 129SvEv mice, respectively. The protocol used was approved by the Monash University Animal Ethics Committee (MIPS.2015.14) and conforms to the Australian Code for the Care and Use of Animals for Scientific Purposes. Male or female mice (12-16-weekold) were killed by $\mathrm{CO}_{2}$ inhalation and cervical dislocation, and tissues of interest dissected and frozen for RNA extractions or ileum and colon dissected and fat removed, fixed overnight in $4 \%(\mathrm{w} / \mathrm{v})$ paraformaldehyde and cryoprotected with $30 \%(\mathrm{w} / \mathrm{v})$ sucrose in diethyl pyrocarbonate-treated phosphate buffered saline (DEPC-PBS) for tissue staining. Fixed tissues were frozen in cryomoulds in Tissue-Tek (OCT, VWR International, QLD, Australia) and stored at $-80^{\circ} \mathrm{C}$ until sectioning.

\section{Cell culture}

Human NCI-H716, LS513 and SW1463 cells were purchased from American Type Culture Collection (Manassas, VA, USA). GLUTag cells (Brubaker et al. 1998) were a kind gift from Professor Fiona M. Gribble (University of Cambridge, UK) with permission from Prof. Daniel J Drucker (University of Toronto, Canada). NCI-H716 cells were grown in suspension and maintained in complete media consisting of RPMI-1640 (Thermo Fisher Scientific) with $5 \%$ foetal bovine serum (FBS). GLUTag cells were grown in high glucose DMEM (Thermo Fisher Scientific) with 10\% (v/v) FBS, and LS513 and SW1463 cells in high glucose DMEM with 5\% (v/v) FBS. Cells were incubated at $37^{\circ} \mathrm{C}$ in a humidified chamber containing 5\% $\mathrm{CO}_{2}$. Cells were seeded onto multi-well plates and grown in complete media for $48 \mathrm{~h}$ before experimentation. NCIH716 cells were plated onto multi-well plates coated with Cultrex basement matrix extract (Trevigen, Gaithersburg, $\mathrm{MD}, \mathrm{USA}$ ) at $100 \mu \mathrm{g} / \mathrm{mL}$ to allow cell adhesion.

\section{RNA isolation and CDNA synthesis}

Total RNA was isolated from mouse tissues, and cell lines using RNeasy mini RNA purification kit (Qiagen) and DNase-treated using the Ambion DNA-free DNase kit (Thermo Fisher Scientific) according to the manufacturer's instructions. cDNA was synthesised from $500 \mathrm{ng}$ RNA in a $10 \mu \mathrm{L}$ reverse transcriptase reaction using iScript Reverse Transcription Supermix kit for RT-qPCR (Bio-Rad). 
qPCR

Quantitative polymerase chain reaction (qPCR) was performed as described previously (Ang et al. 2017) using a Mastercycler ep Realplex machine (Eppendorf, Hamburg, Germany) with the following TaqMan primers and probes (Thermo Fisher Scientific): Mouse - Insl5: Mm04210319_ m1, Rxfp4: Mm00731536_s1, Gcg: Mm00801714_m1, Glp1r: Mm00445292, Actb: Mm02619580_g1; Human - INSL5: Hs00193884_m1, RXFP4: Hs00704281_s1, GCG: Hs01031536_m1, GLP1R: Hs00157705_m1, ACTB: Hs01060665_g1. After denaturation at $95^{\circ} \mathrm{C}$ for $10 \mathrm{~min}$, fluorescence was measured over 40 cycles $\left(95^{\circ} \mathrm{C}\right.$ for $15 \mathrm{~s}$, $60^{\circ} \mathrm{C}$ for $\left.2 \mathrm{~min}\right)$.

\section{Generation of in situ hybridisation probes}

Digoxigenin (DIG)-labelled Insl5 and Rxfp4 in situ hybridisation probes were generated by in vitro transcription (Supplementary methods, see section on Supplementary data given at the end of this article).

\section{Combined in situ hybridisation and immunofluorescence}

For detailed protocol, see Supplementary methods. Briefly, $12 \mu \mathrm{m}$ sections of mouse colon and ileum were cut using a Leica CM3050 cryostat and mounted on Superfrost Plus slides (Thermo Fisher Scientific) and allowed to air-dry for an hour. Sections were hybridised with DIG-labelled Insl5 or $R x f p 4$ probe (1:100 each) overnight at $60^{\circ} \mathrm{C}$, washed and incubated with horseradish peroxidase-(POD, 1:500, Roche) conjugated anti-DIG antibody before tyramide signal amplification with FITC-tyramide. Following in situ hybridisation, sections were blocked (2\% BSA, 0.1\% (v/v) Tween-20 in PBS), incubated with rabbit anti-proglucagon antibody (1:100, ab8055, Abcam) overnight, washed with TBST and incubated with anti-rabbit Alexa594 secondary antibody (1:500, Thermo Fisher Scientific). Fluorescent wide-field images were acquired by tile-scanning using a Nikon Ti-E fluorescence microscope with a $20 \times$ objective and photo-stitched during acquisition in NIS-Elements software (Nikon Instruments).

\section{Alphascreen protein phosphorylation}

Phosphorylation of ERK1/2 (Thr'202/Tyr $\left.{ }^{204}\right)$, AKT (Thr ${ }^{308}$ and Ser ${ }^{473}$ ) and S6RP (Ser235/236) was measured using Alphascreen SureFire kits (Perkin Elmer). GLUTag and LS513 cells were seeded onto 96-well plates and
NCI-H716 cells were prepared in 24-well matrix-coated plates. On the day of experiment, cells were serumstarved for $4-6 \mathrm{~h}$ in low glucose ( $1 \mathrm{~g} / \mathrm{L})$ DMEM to reduce basal phosphorylation levels, and then stimulated with human INSL5 $(100 \mathrm{nM})$ for up to $60 \mathrm{~min}$ in time course studies or with increasing concentrations of peptides $\left(10^{-10}-10^{-6.5} \mathrm{M}\right)$ in concentration-response studies at $5 \mathrm{~min}$ (p-ERK1/2), $15 \mathrm{~min}$ (p-AKT) and $30 \mathrm{~min}$ (p-S6RP). At the end of INSL5 stimulation, cells were lysed and protein phosphorylation was measured as described previously (Ang et al. 2017).

\section{Immunoblotting}

All primary and secondary antibodies were from Cell Signalling Technology. NCI-H716 cells were grown in a 12-well plate and stimulated with INSL5 (100 nM) for up to $60 \mathrm{~min}$ and lysed with $80 \mu \mathrm{L}$ of SDS sample buffer (62.5 mM Tris- $\mathrm{HCl}$ (pH 6.8), 4\% SDS, 20\% glycerol, $0.001 \%$ bromophenol blue and 5\% $\beta$-mercaptoethanol). Cell lysates were transferred to microcentrifuge tubes, sonicated for $10-15 \mathrm{~s}$ to reduce viscosity and boiled at $95^{\circ} \mathrm{C}$ for $5 \mathrm{~min}$ to denature proteins. Protein samples were loaded onto $10 \%$ polyacrylamide gels and separated at $100 \mathrm{~V}$ for $2 \mathrm{~h}$ and electrotransferred to a polyvinyl difluoride membrane $(0.45 \mu \mathrm{m}$, Bio-Rad $)$. Membranes were blocked for $2 \mathrm{~h}$ with 5\% BSA in TBST and incubated overnight at $4^{\circ} \mathrm{C}$ with phospho-ERK1/2 (1:1000; \#9101) or phospho-AKT Ser473 (1:1000; \#9271) rabbit primary antibodies. The following day, membranes were washed 5 times with TBST, incubated with HRP-conjugated anti-rabbit secondary antibody (1:2000; \#7074) at room temperature for $2 \mathrm{~h}$ and immunoblots detected with enhanced chemiluminescence (ECL) using ChemiDoc Imaging System (Bio-Rad). The membranes were then stripped with stripping buffer (62.5 mM Tris- $\mathrm{HCl}$ (pH 6.8), $2 \% \mathrm{SDS}, 100 \mu \mathrm{M} \beta$-mercaptoethanol) for $30 \mathrm{~min}$ at $60^{\circ} \mathrm{C}$, washed 5 times with TBST, re-probed with rabbit primary antibodies against total ERK1/2 (1:1000; \#9102) or total AKT (1:1000; \#9272) and immunoblots detected as before using the ECL detection method.

\section{Inhibition of CAMP accumulation}

Inhibition of forskolin-stimulated cAMP accumulation in NCI-H716 cells was measured using a LANCE cAMP kit (Perkin Elmer). Cells were seeded in 96-well plates and on the day of experiment, incubated in HBSS (Thermo Fisher Scientific) supplemented with $0.5 \mathrm{mM}$ IBMX, $5 \mathrm{mM}$

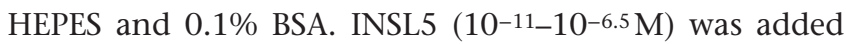


for $15 \mathrm{~min}$ followed by stimulation with forskolin $(3 \mu \mathrm{M})$ for $30 \mathrm{~min}$. Cells were lysed in ice-cold absolute ethanol and air-dried. Pellets containing cAMP were solubilised in $0.3 \%(\mathrm{v} / \mathrm{v})$ Tween-20, $5 \mathrm{mM}$ HEPES and $0.1 \%(\mathrm{w} / \mathrm{v})$ BSA, and cAMP in the solute was measured according to the manufacturer's protocol.

\section{Intracellular $\mathrm{Ca}^{2+}$ mobilisation}

NCI-H716 cells were prepared in a 96-well plate, loaded with the $\mathrm{Ca}^{2+}$ indicator Fluo-4 AM and real-time intracellular $\mathrm{Ca}^{2+}$ mobilisation during INSL5 stimulation measured on a FlexStation (Molecular Devices, Sunnyvale, CA, USA) as previously described (Ang et al. 2017).

\section{GLP-1 secretion}

NCI-H716 cells were grown overnight in complete RPMI media in 96-well plates and serum-starved with vehicle $(0.02 \%$ DMSO) or INSL5 (100 nM) $18 \mathrm{~h}$ prior to experimentation. On the day of experiment, cells were washed with $\mathrm{PBS}$ and incubated in secretion buffer

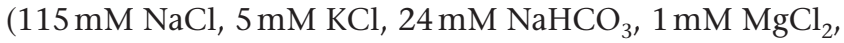
$2.5 \mathrm{mM} \mathrm{CaCl}_{2}, 25 \mathrm{mM}$ HEPES, $5 \mathrm{mM}$ glucose) and vehicle $(0.02 \%$ DMSO) or INSL5 $(100 \mathrm{nM})$ added for $15 \mathrm{~min}$, followed by vehicle (0.04\% DMSO) or secretagogues $(100 \mu \mathrm{M}$ carbachol, $100 \mathrm{nM}$ insulin or $3 \mu \mathrm{M}$ forskolin) for $90 \mathrm{~min}$ (Supplementary Fig. 1). $50 \mu \mathrm{M}$ DPP4 inhibitor (DPP4-010, EMD Millipore) was included in the secretion buffer to prevent GLP-1 degradation. Media was collected and GLP-1 content was measured using an active GLP-1 HTRF kit (Cisbio, Codolet, France) according to the manufacturer's protocol.

\section{Data and statistical analysis}

For RT-qPCR, data were expressed as the relative abundance of the gene of interest relative to the reference gene, $\beta$-actin $(A C T B)$, using the following equation:

$$
\begin{gathered}
2 \Delta \mathrm{Ct}{ }^{*} 1000 \\
\text { where } \Delta \mathrm{Ct}=\mathrm{Ct}_{\text {gene of interest }}-\mathrm{Ct}_{A C T B} .
\end{gathered}
$$

For Alphascreen protein phosphorylation assays, data were expressed as a \% of untreated (basal) response in the time course study or \% vehicle response in the concentration-response study, for inhibition of cAMP accumulation as \% forskolin $(3 \mu \mathrm{M})$ response, for calcium mobilisation as \% basal fluorescence intensity prior to ligand addition, and for GLP-1 secretion assay as picomolar concentration (pM). All graphs were plotted using Prism (v7.0) (GraphPad Software) and concentration-response curves fitted using a three-parameter Hill equation within Prism. INSL5 protein phosphorylation in the Alphascreen time course study was statistically compared to the untreated (basal) response using two-way ANOVA followed by Sidak's multiple comparisons, while the GLP-1 response stimulated by various ligands was statistically compared to the untreated (basal) response using one-way ANOVA followed by Sidak's multiple comparisons test.

\section{Peptides and drugs}

Lyophilized human INSL5 was purchased from Phoenix Pharmaceuticals (Burlingame, CA, USA) and reconstituted. Human insulin (19278), carbachol (C4382) and forskolin (F6886) were from Sigma-Aldrich.

\section{Results}

\section{Expression patterns of Ins/5 and Rxfp4 in mouse tissues}

Since metabolic phenotypes have been reported in mice with genetic ablation of Insl5 (Burnicka-Turek et al. 2012) or Rxfp4 (Grosse et al. 2014), we investigated mRNA expression patterns of Insl5 and $R x f p 4$ by RT-qPCR in the following metabolically relevant mouse tissues: skeletal muscle (hind limb), heart, pancreas, brown adipose tissue (BAT), inguinal adipose tissue (iWAT), epididymal adipose tissue (eWAT), ileum, colon and rectum. Insl5 expression was the highest in colonic mucosa followed by submucosa but was undetectable in external muscle (Fig. 1). Insl5 expression was undetectable in other regions that include ileum, skeletal muscle, heart, pancreas, BAT, iWAT and eWAT. By contrast, the proglucagon mRNA Gcg was highly expressed, as expected, in pancreas where glucagon is synthesised, and also found in ileum, colon and rectum, all regions where GLP-1 is produced (Fig. 1). Using combined in situ hybridisation and immunohistochemistry, Insl5 mRNA was localised in mouse colon to discrete cells that were also immunopositive for the GLP-1 precursor proglucagon (Fig. 2), in agreement with previous studies (Grosse et al. 2014, Lee et al. 2016). In line with our RT-qPCR data, no Insl5 mRNA was detected by in situ hybridisation in mouse ileum, whereas proglucagon immunoreactivity was still observed (Supplementary Fig. 2).

While Insl5 expression was confined to the mouse colorectum, its receptor $R x f p 4$ had a more general tissue expression pattern with transcripts detected at relatively low levels across all the tissues investigated. Rxfp 4 


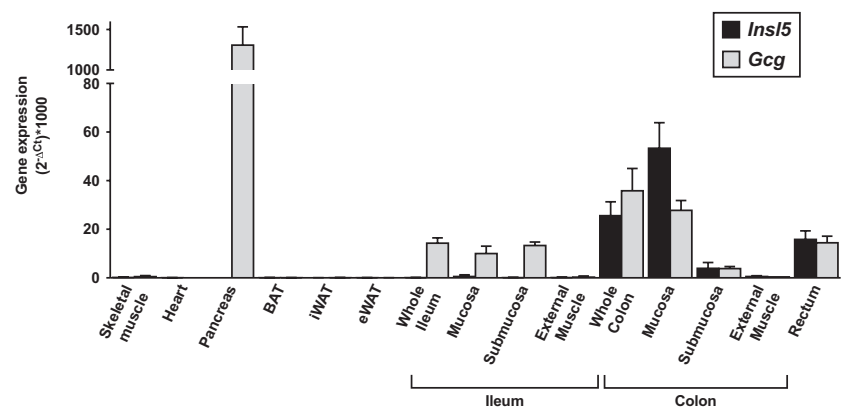

Figure 1

Expression pattern of Ins/5 mRNA in various mouse tissues, as determined by RT-qPCR using Taqman probes. Bars represent mean \pm S.E.M. of 3-6 samples, except $n=2$ for colonic external muscle.

expression was the highest in pancreas and was also detected in heart, skeletal muscle, rectum and all layers of ileum and colon (Fig. 3). In comparison, Glp1r was expressed abundantly in the pancreas, in line with known expression in insulin-producing $\beta$-cells (MacDonald et al. 2002). Consistent with the relatively poor tissue expression in mouse, we found the Rxfp 4 in situ hybridisation signal weak and extremely difficult to detect in the colon. There was a faint perinuclear $R x f p 4$ signal that colocalised with proglucagon immunoreactivity in mouse colonic mucosa (Fig. 4), suggesting that Rxfp 4 may be discretely expressed in a subset of colonic cells such as enteroendocrine

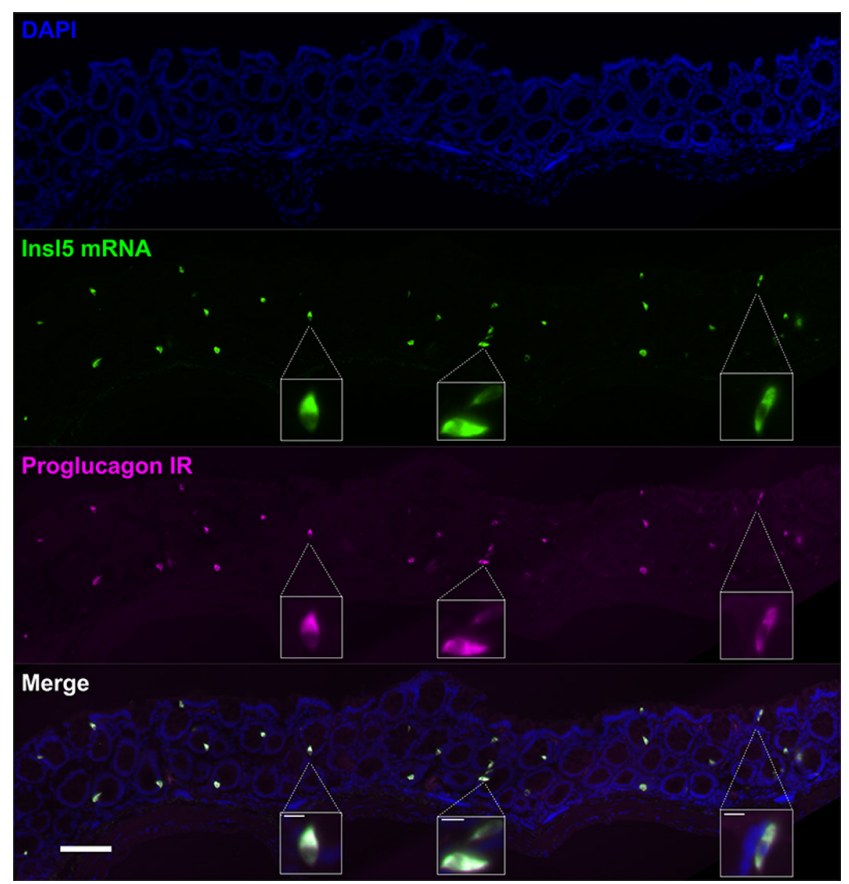

Figure 2

In situ hybridisation using mouse Ins/5 anti-sense probe revealed colocalisation of Ins/5 and proglucagon immunoreactivity in mouse colon. Scale bar $=100 \mu \mathrm{m}$; inset scale bar $=10 \mu \mathrm{m}$.

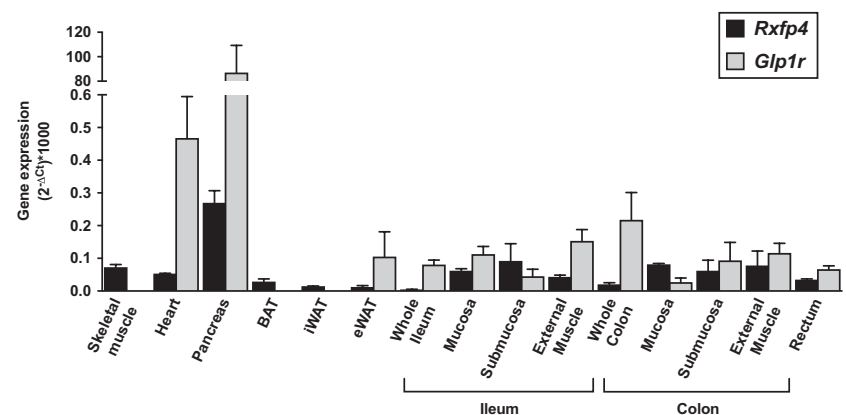

Figure 3

Rxfp4 mRNA expression in various mouse tissues as determined by RT-qPCR using Taqman probes. Bars represent mean \pm s.E.M. of 3-6 samples, except $n=2$ for colonic external muscle.

L-cells. Unlike previously reports, we were not able to detect RXFP4 signals in enteric neurons using the in situ hybridisation approach.

\section{RXFP4 is expressed in human L-cell model NCI-H716} cell line and goblet-like colorectal cell lines LS513 and SW1463, but not in murine L-cell model GLUTag cell line

Our RT-qPCR data, together with transcriptomic data published by others (Yue et al. 2014, Uhlén et al. 2015), indicate that RXFP4 is expressed in the GI tract. Thus, we focused our attention on cell lines with GI origin to investigate whether they express RXFP4 and could signal in response to INSL5. Moreover, INSL5 was recently shown to promote phosphorylation of ERK1/2 and to stimulate GLP-1 secretion in GLUTag cells (Luo et al. 2015). GLUTag cells are a murine model of enteroendocrine L-cells originally derived from a colonic tumour developed from transgenic mice expressing SV40 large $\mathrm{T}$ antigen under the control of the proglucagon promoter (Drucker et al. 1994, Gil-Lozano \& Brubaker 2015) and are widely used to study GLP-1 release in response to a variety of L-cell stimuli (Lan et al. 2012, Parker et al. 2012, Gagnon et al. 2015, Luo et al. 2015). Here, using RT-qPCR, Rxfp4 mRNA was surprisingly undetectable in GLUTag cells. In contrast, Insl5 and $G c g$ were readily detected, with Gcg expressed at a higher level than Insl5 (Fig. 5A). This supports a previous microarray gene expression study of GLUTag cells that also found no Rxfp 4 expression (Trabelsi et al. 2015). In contrast, NCI-H716 cells, a commonly used human model of enteroendocrine L-cells (Reimer et al. 2001, Jang et al. 2007, Lauffer et al. 2009, Lim et al. 2009) originally derived from ascites fluid of a patient with caecal adenocarcinoma (Park et al. 1987, Gagnon \& Brubaker 2015), expressed reasonably high levels of 


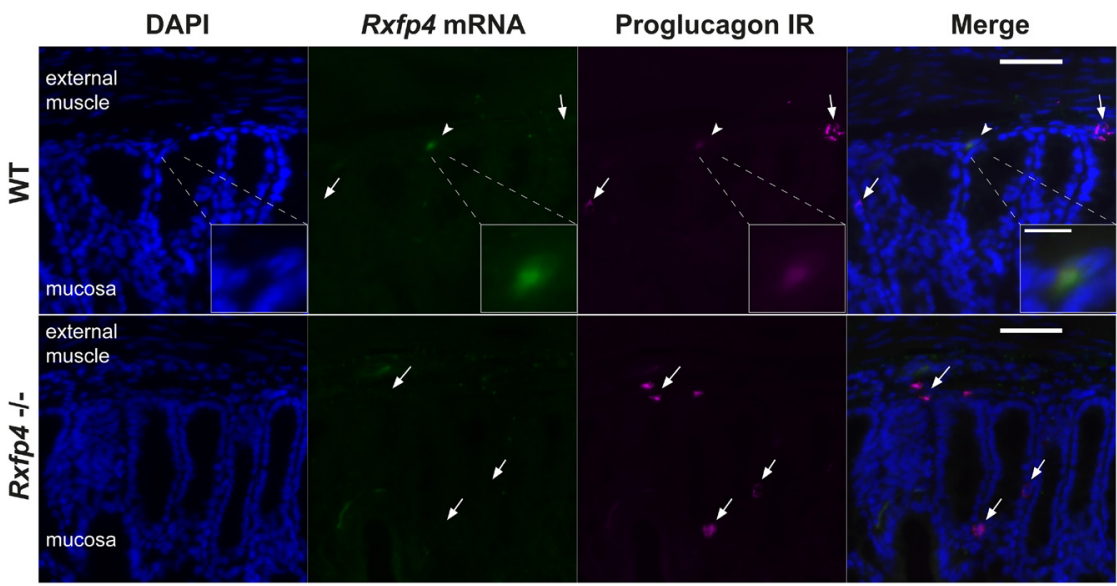

\section{Figure 4}

Localisation of Rxfp4 in mouse colon. Top panel: In situ hybridisation using $R x f p 4$ anti-sense probe revealed a weak $R x f p 4$ signal that colocalised with discrete (arrowhead) but not all (arrow) proglucagon immunoreactive cells of the colon of WT mouse. Bottom panel: Rxfp4 was not detected in proglucagon immunoreactive cells (arrow) of the colon of Rxfp4-I- mouse. Scale bar $=50 \mu \mathrm{m}$, inset scale bar $=10 \mu \mathrm{m}$.

RXFP4. NCI-H716 also expressed GCG abundantly but INSL5 poorly (Fig. 5B). Two goblet-like cell lines, LS513 and SW1463, both derived from patients with Duke's type C mucin-secreting caecal tumour (Leibovitz et al. 1976, Suardet et al. 1992), also expressed reasonably high levels of RXFP4, whereas INSL5 expression was undetectable in LS513 and poor in SW1463 (Fig. 5 C and D). LS513 cells have been used as models to demonstrate protective roles of mucins in epithelial cells (Gustafsson et al. 2013, Sheng et al. 2013, 2017), whereas SW1463 cells are regularly used as a cell model for colorectal cancer (Singh et al. 2012, Pinto et al. 2016, Emons et al. 2017).

\section{INSL5 stimulates phosphorylation of ERK1/2, AKT and S6RP and inhibits CAMP production in $\mathrm{NCl}-\mathrm{H716}$ cells}

Since NCI-H716 and LS513 endogenously expressed RXFP4, we performed pharmacological studies on these cells using the cognate ligand for human RXFP4, human INSL5. In a recombinant cell system stably expressing human RXFP4, INSL5 promoted phosphorylation of ERK1/2, AKT and S6RP and inhibited cAMP production (Ang et al. 2017). ERK1/2 and AKT pathways are widely implicated in cellular proliferation, differentiation, growth and survival (Manning \& Cantley 2007, Turjanski et al. 2007), while S6RP is involved in protein synthesis (Ruvinsky \& Meyuhas 2006). In time course experiments, exposure of NCI-H716 cells to INSL5 (100 nM) for up to $60 \mathrm{~min}$ produced phosphorylation of ERK1/2 (Thr ${ }^{202} /$ $\left.\mathrm{Tyr}^{204}\right)$, AKT (Thr ${ }^{308}$ and Ser ${ }^{473}$ ) and S6RP Ser ${ }^{235 / 236 .}$ Maximum ERK1/2 phosphorylation occurred at $5 \mathrm{~min}$, AKT (Thr ${ }^{308}$ and Ser ${ }^{473}$ ) phosphorylation at $15 \mathrm{~min}$ and S6RP phosphorylation at $30 \mathrm{~min}$ (Fig. 6A, B, C and D). INSL5 concentration-response relationships in NCI-H716 cells were constructed at time points corresponding to maximum protein phosphorylation. INSL5 (0.1-300 nM) caused concentration-dependent phosphorylation of ERK1/2 (Fig. 6E), AKT (Thr ${ }^{308}$ and Ser ${ }^{473}$; Fig. 6F and G) and S6RP (Fig. 6H) with $\mathrm{pEC}_{50}$ values ranging from 7.9 to 8.4. In addition, immunoblots for ERK1/2 and AKT (Ser ${ }^{473}$ ) performed in NCI-H716 cells following INSL5 stimulation (100 nM), showed similar phosphorylation patterns (Fig. 6I and J) to those observed in the Alphascreen time course assays. Exposure of NCI-H716 cells to human INSL5 (0.1-300 nM) also produced concentration-dependent inhibition of cAMP accumulation in response to forskolin $(3 \mu \mathrm{M}) \quad\left(\mathrm{pEC}_{50}=8.0 \pm 0.3\right.$; Fig. $\left.6 \mathrm{~K}\right)$ reflecting activation of $\mathrm{G}_{\mathrm{i} / \mathrm{o}}$-coupled RXFP4. Since $\mathrm{Ca}^{2+}$ mobilisation is an important mechanism leading to GLP-1 secretion (for review see Reimann et al. 2012), the effect of INSL5 on

\section{A

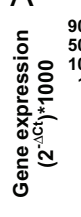

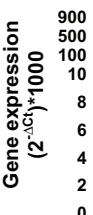

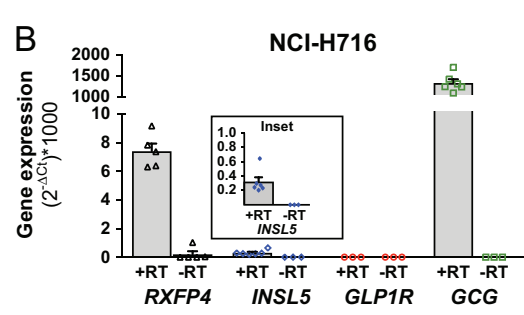

C
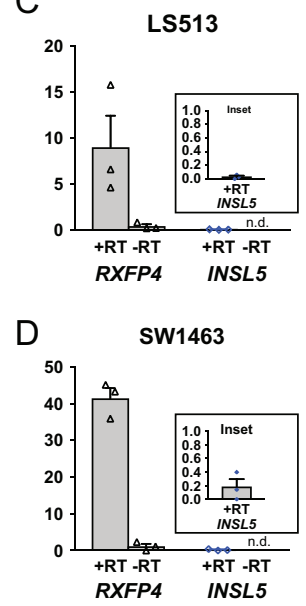

Figure 5

RXFP4, INSL5, GLP1R and GCG gene expression as determined by RT-qPCR using TaqMan probes in (A) mouse GLUTag L-cells, (B) human NCl-H716 L-cells and goblet-like human colorectal cell lines (C) LS513 and (D) SW1463. Bars represent mean \pm s.E.M. n.d., not determined. $-R T$ : qPCR performed on RNA without reverse transcription. A full colour version of this figure is available at https://doi.org/10.1530/JME-17-0152. 

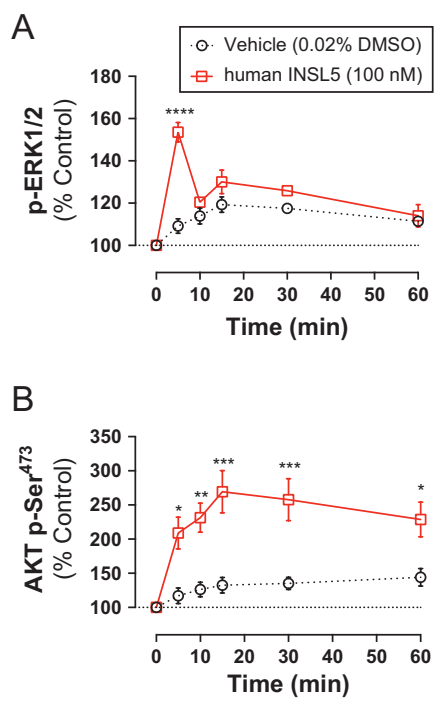

C
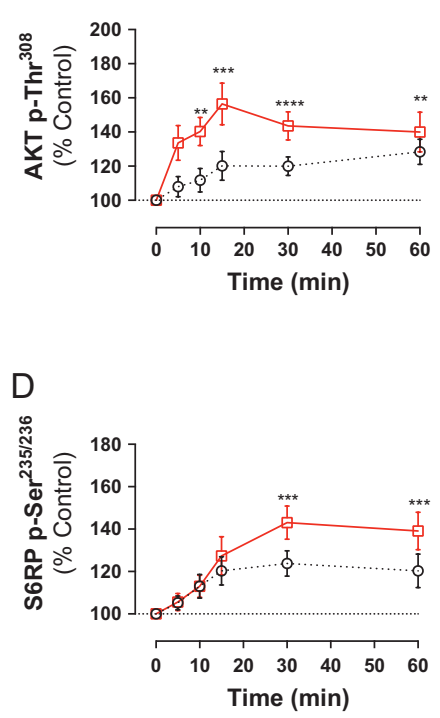

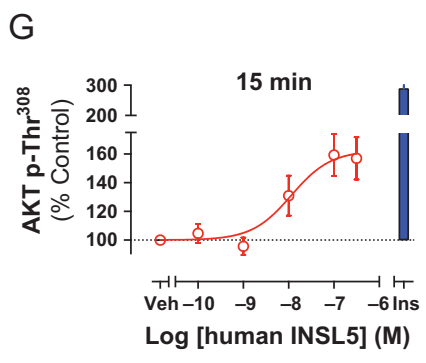

$\mathrm{H}$

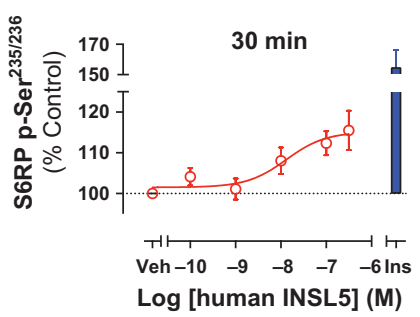

E

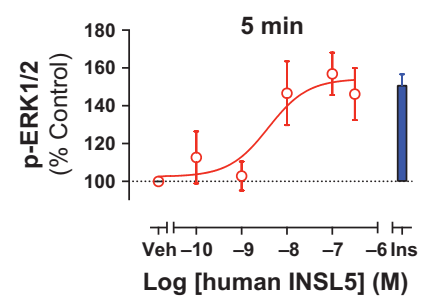

F

I

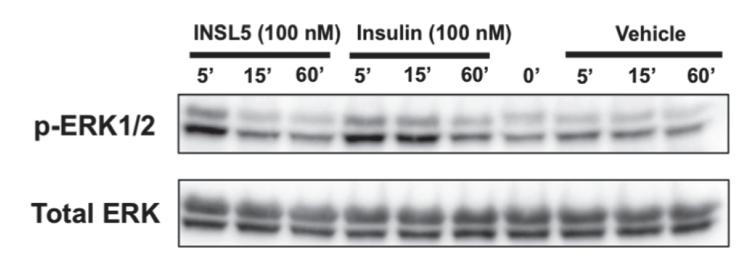

J

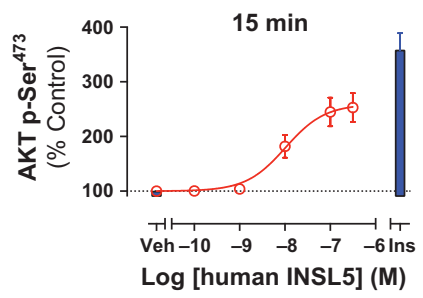

AKT p-Ser $473 \longrightarrow-\cdots+\cdots$

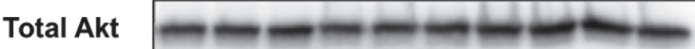

$\mathrm{K}$

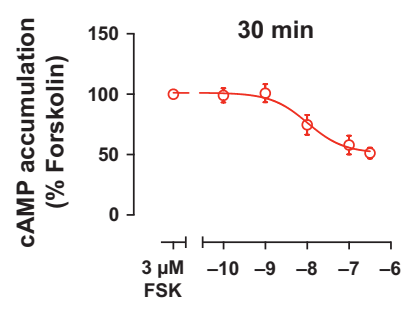

Log [human INSL5] (M)

L

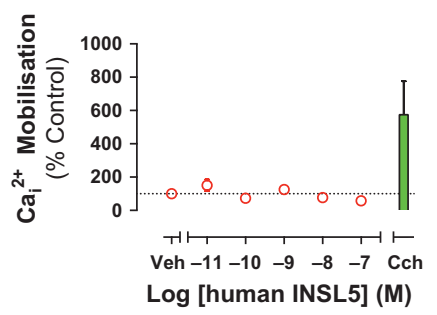

Figure 6

Signalling pathways activated by INSL5 in NCl-H716 cells. NCI-H716 cells were stimulated with INSL5 (100 nM) at various time points or with increasing concentrations of INSL5 (0.1-300 nM) and assessed for protein phosphorylation using Alphascreen assays. INSL5 (100 nM) stimulated phosphorylation of (A, E) ERK1/2 $(n=5),(B, F)$ AKT Ser $473(n=5),(C, G)$ AKT Thr308 $(n=5)$ and (D, H) S6RP Ser $235 / 236(n=5)$ in a time- and concentration-dependent manner. Blue bars indicate phosphorylation stimulated by human insulin $(100 \mathrm{nM}) .{ }^{*} P<0.05 ; * * P<0.01, * * * P<0.001 ; * * * *<0.0001$ vs control, two-way repeated measures ANOVA with Sidak's multiple comparisons test. $(\mathrm{I}, \mathrm{J})$ Representative immunoblots showing phosphorylation patterns of ERK $1 / 2$ and AKT Ser 773 in NCI-H716 cells treated with INSL5 (100 nM). (K) Effect of INSL5 on CAMP production. (L) Lack of effect of INSL5 up to $100 \mathrm{nM}$ on intracellular Ca2+ mobilisation $(n=3)$. Green bar represents carbachol response $(C \mathrm{Ch}, 30 \mu \mathrm{M}$, positive control). Data points and bars represent mean \pm S.E.M. of independent experiments. A full colour version of this figure is available at https://doi.org/10.1530/JME-17-0152.

intracellular $\mathrm{Ca}^{2+}$ mobilisation was also investigated. INSL5 treatment up to $100 \mathrm{nM}$ failed to stimulate a detectable $\mathrm{Ca}^{2+}$ response, whereas the muscarinic acetylcholine receptor agonist carbachol $\left(10^{-4} \mathrm{M}\right)$ caused a robust $\mathrm{Ca}^{2+}$ response (Fig. 6L).

Intriguingly, we were unable to observe INSL5 signalling in LS513 cells (Supplementary Fig. 3A, B, C, D and $\mathrm{E}$ ), even though RXFP4 was clearly expressed in these cells (Fig. 5C). In addition, we were unable to adequately perform further pharmacological studies in SW1463 due to the poor growth of this cell line. Consistent with a lack of $R x f p 4$ expression in GLUTag cells, treatment with mouse INSL5 $(100 \mathrm{nM})$ over $60 \mathrm{~min}$, failed to produce phosphorylation of AKT (Thr ${ }^{308}$ or Ser ${ }^{473}$ ) or S6RP Ser ${ }^{235 / 236}$ (Supplementary Fig. 4) both signalling events associated with RXFP4 activation (Ang et al. 2017). In contrast, 
insulin $(100 \mathrm{nM})$ stimulated a robust AKT and S6RP response in the same cells.

\section{Effects of acute and chronic administration of INSL5 on GLP-1 secretion from $\mathrm{NCl}-\mathrm{H} 716$ cells}

NCI-H716 is a model of human enteroendocrine L-cells, and as such we investigated the effects of INSL5 on GLP-1 secretion (Fig. 7). In cells exposed to chronic (18 h) vehicle, acute INSL5 treatment $(100 \mathrm{nM})$ had no significant effect on basal, carbachol or insulin-stimulated GLP-1 secretion but significantly inhibited forskolin-stimulated GLP-1 secretion $(P<0.01)$. However, in cells exposed to chronic (18h) INSL5, acute INSL5 treatment had no effect on basal secretion and failed to inhibit forskolin-stimulated GLP-1 secretion, likely due to RXFP4 desensitisation by chronic INSL5 pre-treatment (Ang et al. 2017) or possibly downregulation of signalling effectors. Interestingly, cells chronically pre-treated with INSL5 displayed an increase in basal GLP-1 secretion $(P<0.001)$. This was not due to increased synthesis of GLP-1 precursor peptide proglucagon, since proglucagon peptide content remained unchanged in these cells (Supplementary Fig. 5A) or by an increased number of cells (Supplementary Fig. 5B).

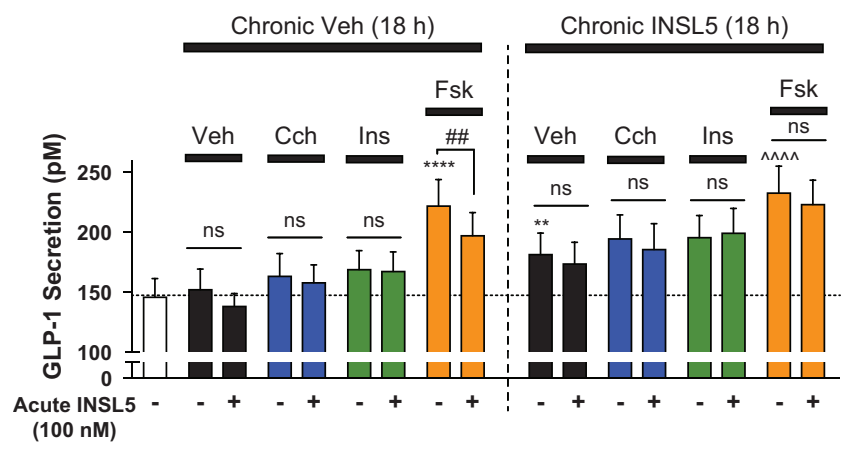

Figure 7

Effect of INSL5 on GLP-1 secretion from $\mathrm{NCl}-\mathrm{H} 716$ cells. $\mathrm{NCl}-\mathrm{H} 716$ cells were prepared as described in materials and methods. $18 \mathrm{~h}$ before the start of GLP-1 secretion, cells were chronically pre-incubated in serumfree media in the presence of vehicle $(0.02 \%$ DMSO) or INSL5 (100 nM). On the day of experiment, cells were washed and acutely stimulated with vehicle $(0.02 \%$ DMSO) or INSL5 $(100 \mathrm{nM})$ for $15 \mathrm{~min}$ followed by co-treatment with either vehicle (Veh; 0.04\% DMSO) or the GLP-1 secretagogues carbachol (Cch, $100 \mu \mathrm{M})$, insulin (Ins, $100 \mathrm{nM})$ or forskolin (Fsk, $3 \mu \mathrm{M}$ ) for $90 \mathrm{~min}$, and media assayed for active GLP-1. $* * P<0.01$; $* * * * P<0.0001$ vs acute vehicle response in cells chronically pre-treated with vehicle. ${ }^{\wedge \wedge \wedge} P<0.0001$ vs acute vehicle response in cells chronically pre-treated with INSL5. \#\# $P<0.01$ vs forskolin treatment alone; Ns, non-significant. One-way repeated measures ANOVA with Sidak's multiple comparisons test. Bars represent mean \pm S.E.M. of $n=6$ independent experiments. A full colour version of this figure is available at https://doi.org/10.1530/JME-17-0152.

\section{Discussion}

In this study, we demonstrate that Insl5 mRNA is expressed mainly in the mouse colonic mucosa in discrete cells that are also immunopositive for the GLP-1 precursor proglucagon, confirming Insl5 expression in enteroendocrine L-cells (Grosse et al. 2014, Lee et al. 2016). Indeed, a similar co-expression pattern was observed in the human colon (Grosse et al. 2014) suggesting that INSL5 likely has important biological functions across different species. By comparison, we found Rxfp 4 expression in mouse tissues to be weaker, less region specific and more difficult to detect than Insl5. We were unable to detect Rxfp4 in enteric neurons by in situ hybridisation, unlike previous reports (Grosse et al. 2014). The disparity may reflect the different hybridisation strategies employed, and different sensitivities between fluorescent (present study) and chromogenic detection methods. Other approaches such as RNAscope, $R x f p 4$ Cre reporter mouse line or receptor autoradiography would be useful to clarify the expression and localisation of RXFP4 in native tissues.

Although expression of $R x f p 4$ is detectable in mouse pancreas, the level is only $4 \%$ of that seen in NCI-H716 cells and less than $0.3 \%$ of that seen for Glp1r in pancreas. These data are consistent with a number of RNA sequencing studies on both mouse and human pancreatic islets. In 4-6 independent preparations of mouse freshly isolated primary $\alpha, \beta$ and $\delta$ cells, $R x f p 4$ has FPKM values ranging from 0.0 to 0.26 (average 0.04) (Adriaenssens et al. 2016). These values are negligible compared to those for GPCRs known to be important in islet function, for example, an average FPKM of 207 for Glp1r and 9.0 for Sstr3 in mouse purified $\beta$ cells. Moreover, we previously showed that the mouse insulinoma $\beta$-cell line MIN6 do not express $R x f p 4$ (Ang et al. 2017). Similarly, human whole pancreatic islets display no detectable RXFP4 transcripts (Eizirik et al. 2012), and 11 preparations of human FACS-purified $\beta$-cells show negligible RPKM values ranging from 0.0 to 0.11 (Nica et al. 2013). An FPKM or RPKM value greater than 1.0 is considered significant in samples of RNA derived from homogeneous cell populations (Hebenstreit et al. 2011, Adriaenssens et al. 2016), and in the same human preparations, the RPKM values for GLP1R ranged from 25.7 to 73.2 and those for SSTR3 ranged from 7.7 to 21.8. Thus, it is highly unlikely that pancreatic islets in mouse or human are a physiologically relevant target for INSL5 action.

Transcriptomic analyses by others have revealed a slightly different pattern of RXFP4 expression between human and mouse tissues. Whereas in human, RXFP4 is expressed in duodenum, small intestine, colon and rectum 
but not in lung, in mouse $R x f p 4$ is expressed in colon and lung but not in duodenum or small intestine (Yue et al. 2014, Uhlén et al. 2015) (Supplementary Fig. 6). It is also noteworthy that the RXFP4 amino acid sequence is highly conserved in human, monkey (97\% homology), cow (85\% homology) and pig (87\% homology) but less so in mouse (74\% homology), and $R x f p 4$ is a pseudogene in rat (Chen et al. 2005). Thus, RXFP4 may have different and perhaps more evolved biological functions in humans compared to mice. This also highlights the importance of using a human model such as NCI-H716 cells when studying the biological functions of INSL5 acting on RXFP4.

The effects of INSL5 signalling were examined on GLP-1 release from NCI-H716 cells. In general, we found that the response window for GLP-1 secretion in NCI-H716 cells was small but detectable, in agreement with a recent study showing a weak but comparable GLP-1 response in the same cells (Kuhre et al. 2016). In the current study, acute INSL5 treatment had no significant effect on basal GLP-1 release or on release in response to the secretagogues carbachol or insulin, but INSL5 did inhibit GLP-1 release in response to the adenylyl cyclase activator forskolin. Inhibition of GLP-1 secretion by INSL5 is consistent with activation of $\mathrm{G} \alpha_{\mathrm{i} / 0}$-coupled RXFP4, inhibition of adenylyl cyclase activity and a decrease in cAMP production (Ang et al. 2017), since cAMP is upstream of GLP-1 secretion in L-cells (Reimann et al. 2012). For instance, stimulation of either the $\mathrm{G \alpha}_{\mathrm{i} / \mathrm{o}}$-coupled somatostatin receptor SSTR5 or the galanin receptor GALR1 inhibits GLP-1 secretion (Chisholm \& Greenberg 2002, Psichas et al. 2016).

Physiologically, the INSL5-RXFP4 system may constitute an L-cell feedback mechanism that inhibits GLP-1 secretion at times when the hormone is not required i.e. during the fasting state and/or at the end of the fedstate when the glucose-lowering action of GLP-1 is no longer required. Consistent with this notion, plasma INSL5 levels peak during fasting and are suppressed following food intake (Grosse et al. 2014), a trend that opposes that of GLP-1 (Hornnes et al. 1980, Ørskov et al. 1996). The inhibitory action of INSL5 on GLP-1 secretion suggests a possible autocrine/paracrine mechanism resembling that of somatostatin (Chisholm \& Greenberg, 2002). Nevertheless, the inhibition of GLP-1 secretion by INSL5 is modest in NCI-H716 cells ( $30 \%$ inhibition of forskolin-induced GLP-1 release). Given that regulation of GLP-1 release in L-cells is complex and governed by multiple signalling mechanisms including membrane depolarisation and $\mathrm{Ca}^{2+}$ influx, as well as cAMP (Reimann et al. 2006), it is possible that the inhibitory effect of INSL5 on GLP-1 release in this system may be less significant than that observed in a physiological setting. In addition, the mechanisms that control INSL5 release - whether by neural, endocrine, paracrine and/or autocrine pathways - are still unknown.

Interestingly, chronic INSL5 pre-treatment resulted in a somewhat unexpected increase in basal GLP-1 secretion that could not be explained by an increase in proglucagon content. One speculative mechanism for this observation is a phenomenon known as heterologous sensitisation of adenylyl cyclase by $\mathrm{G}_{\mathrm{i} / \mathrm{o}}$-coupled receptors (see review by Brust et al. 2015). Indeed, a number of $\mathrm{G}_{\mathrm{i} / \mathrm{o}}$-coupled receptors including the $\delta$-opioid receptor, $\mu$-opioid receptor and dopamine $\mathrm{D}_{2}$ receptor display a paradoxical enhancement of basal and/or Gs-mediated cAMP production following prolonged agonist stimulation (Watts et al. 2001, Clark et al. 2004, Zhang et al. 2006). Therefore, it is possible that prolonged INSL5 stimulation could lead to heterologous sensitisation of adenylyl cyclase to produce enhanced cAMP signalling in NCI-H716 cells, and hence, a resultant increase in GLP-1 secretion. In addition, as demonstrated in this study, INSL5 activates ERK1/2 and AKT signalling pathways both of which have been implicated in stimulation of GLP-1 secretion from L-cells (Lim et al. 2009, Gagnon et al. 2015). Thus, we speculate that acute INSL5 treatment inhibits GLP-1 secretion by coupling to $\mathrm{G}_{\mathrm{i} / \mathrm{o}}$ proteins, whereas chronic INSL5 treatment potentiates the secretory capacity of L-cells by sensitisation of adenylyl cyclase and/or activation of ERK1/2 and AKT signalling pathways, i.e. INSL5 appears to play a role in mediating both short- and long-term L-cell function.

Although transformed cell lines are relatively easy to grow and maintain compared to isolated primary cells, there are caveats to be considered when using them. NCIH716 and GLUTag are derived from intestinal carcinoma cells that may not necessarily reflect primary L-cells (Kuhre et al. 2016). Indeed, both cell lines produce and secrete high levels of GLP-1 and GLP-2 but, unlike primary L-cells, both also produce somatostatin (SST) even though SSTproducing and GLP-1-producing cells are thought to have arisen from different stages of enteroendocrine lineage commitment (Egerod et al. 2012, Kuhre et al. 2016). Furthermore, NCI-H716 cells reflect neither proximal nor distal primary L-cells since they are undifferentiated in nature (Park et al. 1987) and do not produce nor secrete CCK or PYY (Kuhre et al. 2016). In addition, regulation of the proglucagon gene in these cells differs from other systems (Cao et al. 2003). In spite of these limitations, NCIH716 cells do express high levels of the proglucagon gene GCG as well as RXFP4, but INSL5 poorly (Fig. 5B). A more physiologically relevant model, such as mixed primary 
intestinal cell culture (Reimann et al. 2008) would be necessary to clarify the role of INSL5 in primary L-cells.

The current study revealed no Rxfp 4 expression in GLUTag cells and no INSL5-stimulated cell signalling, unlike a previous report (Luo et al. 2015). Discrepancies in gene expression between GLUTag cells in different laboratories may reflect genomic and transcriptomic variability, possibly arising from differences in culture methods and conditions (Frattini et al. 2015). Thus, in our hands, GLUTag cells were not an appropriate model to study the role of RXFP4 signalling on GLP-1 release. Furthermore, in our hands, LS513 cells were unresponsive to INSL5 treatment even though the cells did express RXFP4. It may simply be a case of the mRNA being expressed but not the protein for RXFP4. Another possible explanation is that gel-forming mucus secreted from these cells may actually form a physical barrier at the cell surface that prevented INSL5 access to membrane-bound RXFP4 or even adsorbs peptide but allows small molecules to diffuse across and activate their receptors. In addition, the lack of INSL5 response may be explained by a polarised RXFP4 localisation at the basolateral membrane of LS513 cells that is inaccessible under the current conventional culture method. Indeed, bile acids stimulate GLP-1 secretion predominantly by accessing the receptor GBPAR1 located at the basolateral surface of L-cells (Brighton et al. 2015).

In vivo, Insl5-/- mice exhibit mild impairment in glucose metabolism compared to WT mice as demonstrated in glucose tolerance tests (Burnicka-Turek et al. 2012, Lee et al. 2016). Interestingly, however, this metabolic phenotype is not observed in $R x f p 4-/-$ mice (Grosse et al. 2014). In humans, single nucleotide polymorphisms of RXFP4 are associated with increased body mass index (BMI) and obesity (Munro et al. 2012), indicating that INSL5-RXFP4 may have important roles in controlling energy balance. Here, our results provide further evidence for a metabolic function of INSL5 by showing that this peptide activates multiple signalling pathways in the human L-cell model NCIH716 cell line and functions to regulate GLP-1 secretion. Nevertheless, a previous study reported that plasma GLP-1 levels were unaltered in Insl5-/- mice compared to WT mice at baseline and following oral glucose administration (Burnicka-Turek et al. 2012). However, these mice lacked the Insl5 gene since birth and therefore in theory could have developed compensatory mechanisms on L-cell secretory function that substitute for the loss of Insl5. To this end, it would be useful to investigate the effect of exogenous INSL5 administration and also the effect of switching on Insl5 gene expression e.g. in a tetracycline inducible system in a mouse model, on plasma GLP-1 levels.
In conclusion, we have shown that (1) Insl5 is expressed in enteroendocrine L-cells in mouse colon and its receptor $R x f p 4$ is expressed in the various tissues including the GI tract and (2) INSL5 activates multiple signalling pathways in the human L-cell model NCIH716 cell line that expresses RXFP4 and regulates GLP-1 release differentially depending on the duration of agonist exposure. Understanding of the underlying signal transduction mechanisms stimulated by INSL5 in a biologically relevant cell culture model is a critical step in elucidating the function of this novel gut hormone.

\section{Supplementary data}

This is linked to the online version of the paper at https://doi.org/10.1530/ JME-17-0152.

\section{Declaration of interest}

The authors declare that there is no conflict of interest that could be perceived as prejudicing the impartiality of the research reported.

\section{Funding}

This work is supported by an Australian National Health and Medical Research Council (NHMRC) program grant (1055134; R J S). SY A is a recipient of the Monash Graduate Scholarship (MGE) and Monash International Postgraduate Research Scholarship (MIPRS). D S H is supported by a NHMRC Career Development Fellowship (545952). Research at the Florey was supported by an ARC Linkage grant to RADB (LP120100654) and by the Victorian Government Operational Infrastructure Support Program. R A D B is supported by an NHMRC Research Fellowship.

\section{Author contribution statement}

S Y A planned and performed the experiments and wrote the manuscript. $B$ A E provided research ideas, advised on gene expression experiments and designed hybridisation probes. D P P assisted in dissection and provided advice on immunofluorescence. $R B$ and $J D$ provided assistance and advice for in situ hybridisation. R A D B and M K provided research and manuscript ideas. D S H managed animals, assisted in dissection and provided research and manuscript ideas. R J S conceived the study, provided research ideas and wrote the manuscript.

\section{Acknowledgement}

The authors thank Josh Conner (Medicinal Chemistry, Monash Institute of Pharmaceutical Sciences, Monash University, Australia) for synthesising FITC-tyramide used for in situ hybridisation in this study and Cameron Nowell for excellent technical assistance.

\section{References}

Adriaenssens AE, Svendsen B, Lam BYH, Yeo GSH, Holst JJ, Reimann F \& Gribble FM 2016 Transcriptomic profiling of pancreatic alpha, beta and delta cell populations identifies delta cells as a principal target for ghrelin in mouse islets. Diabetologia 59 2156-2165. (https://doi. org/10.1007/s00125-016-4033-1) 
Ang SY, Hutchinson DS, Patil N, Evans BA, Bathgate RA, Halls ML, Hossain MA, Summers RJ \& Kocan M 2017 Signal transduction pathways activated by insulin-like peptide 5 at the relaxin family peptide RXFP4 receptor. British Journal of Pharmacology $\mathbf{1 7 4}$ 1077-1089. (https://doi.org/10.1111/bph.13522)

Brighton CA, Rievaj J, Kuhre RE, Glass LL, Schoonjans K, Holst JJ, Gribble FM \& Reimann F 2015 Bile acids trigger GLP-1 release predominantly by accessing basolaterally located $\mathrm{G}$ protein-coupled bile acid receptors. Endocrinology 156 3961-3970. (https://doi. org/10.1210/en.2015-1321)

Brubaker PL, Schloos J \& Drucker DJ 1998 Regulation of glucagon-like peptide-1 synthesis and secretion in the GLUTag enteroendocrine cell line. Endocrinology 139 4108-4114. (https://doi.org/10.1210/ endo.139.10.6228)

Brust TF, Conley JM \& Watts VJ 2015 Gxi/o-coupled receptor-mediated sensitization of adenylyl cyclase: 40 years later. European Journal of Pharmacology 763 223-232. (https://doi.org/10.1016/j. ejphar.2015.05.014)

Burnicka-Turek O, Mohamed BA, Shirneshan K, Thanasupawat T, Hombach-Klonisch S, Klonisch T \& Adham IM 2012 INSL5-deficient mice display an alteration in glucose homeostasis and an impaired fertility. Endocrinology 153 4655-4665. (https://doi.org/10.1210/ en.2012-1161)

Cao X, Flock G, Choi C, Irwin DM \& Drucker DJ 2003 Aberrant regulation of human intestinal proglucagon gene expression in the NCI-H716 cell line. Endocrinology 144 2025-2033. (https://doi. org/10.1210/en.2002-0049)

Chen J, Kuei C, Sutton SW, Bonaventure P, Nepomuceno D, Eriste E, Sillard R, Lovenberg TW \& Liu C 2005 Pharmacological characterization of relaxin-3/INSL7 receptors GPCR135 and GPCR142 from different mammalian species. Journal of Pharmacology and Experimental Therapeutics 312 83-95. (https://doi.org/10.1124/jpet.104.073486)

Chisholm C \& Greenberg GR 2002 Somatostatin-28 regulates GLP-1 secretion via somatostatin receptor subtype 5 in rat intestinal cultures. American Journal of Physiology: Endocrinology and Metabolism 283 E311-E317. (https://doi.org/10.1152/ajpendo.00434.2001)

Clark MJ, Neubig RR \& Traynor JR 2004 Endogenous regulator of G protein signaling proteins suppress $\mathrm{G} \alpha \mathrm{O}$-dependent, $\mu$-opioid agonistmediated adenylyl cyclase supersensitization. Journal of Pharmacology and Experimental Therapeutics 310 215-222. (https://doi.org/10.1124/ jpet.103.064824)

Drucker DJ, Jin T, Asa SL, Young TA \& Brubaker PL 1994 Activation of proglucagon gene transcription by protein kinase-A in a novel mouse enteroendocrine cell line. Molecular Endocrinology 8 1646-1655. (https://doi.org/10.1210/mend.8.12.7535893)

Egerod KL, Engelstoft MS, Grunddal KV, Nøhr MK, Secher A, Sakata I, Pedersen J, Windeløv JA, Füchtbauer E-M, Olsen J, et al. 2012 A major lineage of enteroendocrine cells coexpress CCK, secretin, GIP, GLP-1, PYY, and neurotensin but not somatostatin. Endocrinology 153 5782-5795. (https://doi.org/10.1210/en.2012-1595)

Eizirik DL, Sammeth M, Bouckenooghe T, Bottu G, Sisino G, IgoilloEsteve M, Ortis F, Santin I, Colli ML, Barthson J, et al. 2012 The human pancreatic islet transcriptome: expression of candidate genes for type 1 diabetes and the impact of pro-inflammatory cytokines. PLoS Genetics $\mathbf{8}$ e1002552. (https://doi.org/10.1371/journal.pgen.1002552)

Emons G, Spitzner M, Reineke S, Möller J, Auslander N, Kramer F, Hu Y, Beissbarth T, Wolff HA, Rave-Fränk M, et al. 2017

Chemoradiotherapy resistance in colorectal cancer cells is mediated by Wnt/ $\beta$-catenin signaling. Molecular Cancer Research 15 1481-1490. (https://doi.org/10.1158/1541-7786.MCR-17-0205)

Frattini A, Fabbri M, Valli R, De Paoli E, Montalbano G, Gribaldo L, Pasquali F \& Maserati E 2015 High variability of genomic instability and gene expression profiling in different HeLa clones. Scientific Reports 5 15377. (https://doi.org/10.1038/srep15377)

Gagnon J \& Brubaker PL 2015 NCI-H716 cells. In The Impact of Food Bioactives on Health, pp 221-228. Springer International Publishing: Cham, Switzerland. (https://doi.org/10.1530/JME-11-0114)
Gagnon J, Baggio LL, Drucker DJ \& Brubaker PL 2015 Ghrelin is a novel regulator of GLP-1 secretion. Diabetes 64 1513-1521. (https://doi. org/10.2337/db14-1176)

Gil-Lozano M \& Brubaker PL 2015 Murine GLUTag cells. In The Impact of Food Bioactives on Health, pp 229-238. Springer International Publishing. (https://doi.org/10.1007/978-3-319-16104-4_21)

Grosse J, Heffron H, Burling K, Akhter Hossain M, Habib AM, Rogers GJ, Richards P, Larder R, Rimmington D, Adriaenssens AA, et al. 2014 Insulin-like peptide 5 is an orexigenic gastrointestinal hormone. PNAS 111 11133-11138. (https://doi.org/10.1073/pnas.1411413111)

Gunawardene AR, Corfe BM \& Staton CA 2011 Classification and functions of enteroendocrine cells of the lower gastrointestinal tract. International Journal of Experimental Pathology 92 219-231. (https:// doi.org/10.1111/j.1365-2613.2011.00767.x)

Gustafsson JK, Navabi N, Rodriguez-Piñeiro AM, Alomran AHA, Premaratne P, Fernandez HR, Banerjee D, Sjövall H, Hansson GC \& Lindén SK 2013 Dynamic changes in mucus thickness and ion secretion during Citrobacter rodentium infection and clearance. PLOS ONE 8 e84430. (https://doi.org/10.1371/journal. pone.0084430)

Halls ML, Bathgate RA, Sutton SW, Dschietzig TB \& Summers RJ 2015 International union of basic and clinical pharmacology. XCV. Recent advances in the understanding of the pharmacology and biological roles of relaxin family peptide receptors $1-4$, the receptors for relaxin family peptides. Pharmacological Reviews 67 389-440. (https://doi. org/10.1124/pr.114.009472)

Hebenstreit D, Fang M, Gu M, Charoensawan V, van Oudenaarden A \& Teichmann SA 2011 RNA sequencing reveals two major classes of gene expression levels in metazoan cells. Molecular Systems Biology 7 497. (https://doi.org/10.1038/msb.2011.28)

Hornnes PJ, Kühl C, Holst JJ, Lauritsen KB, Rehfeld JF \& Schwartz TW 1980 Simultaneous recording of the gastro-entero-pancreatic hormonal peptide response to food in man. Metabolism Clinical and Experimental 29 777-779. (https://doi.org/10.1016/0026-0495(80)90203-6)

Jang H-J, Kokrashvili Z, Theodorakis MJ, Carlson OD, Kim B-J, Zhou J, Kim HH, Xu X, Chan SL, Juhaszova M, et al. 2007 Gut-expressed gustducin and taste receptors regulate secretion of glucagon-like peptide-1. PNAS 104 15069-15074. (https://doi.org/10.1073/ pnas.0706890104)

Kuhre RE, Wewer Albrechtsen NJ, Deacon CF, Balk-Møller E, Rehfeld JF, Reimann F, Gribble FM \& Holst JJ 2016 Peptide production and secretion in GLUTag, NCI-H716, and STC-1 cells: a comparison to native L-cells. Journal of Molecular Endocrinology 56 201-211. (https:// doi.org/10.1530/JME-15-0293)

Lan H, Lin HV, Wang CF, Wright MJ, Xu S, Kang L, Juhl K, Hedrick JA \& Kowalski TJ 2012 Agonists at GPR119 mediate secretion of GLP-1 from mouse enteroendocrine cells through glucose-independent pathways. British Journal of Pharmacology 165 2799-2807. (https:// doi.org/10.1111/j.1476-5381.2011.01754.x)

Lauffer LM, Iakoubov R \& Brubaker PL 2009 GPR119 is essential for oleoylethanolamide-induced glucagon-like peptide- 1 secretion from the intestinal enteroendocrine L-cell. Diabetes 58 1058-1066. (https://doi.org/10.2337/db08-1237)

Lee YS, De Vadder F, Tremaroli V, Wichmann A, Mithieux G \& Bäckhed F 2016 Insulin-like peptide 5 is a microbially regulated peptide that promotes hepatic glucose production. Molecular Metabolism 5 263-270. (https://doi.org/10.1016/j. molmet.2016.01.007)

Leibovitz A, Stinson JC, McCombs WB, McCoy CE, Mazur KC \& Mabry ND 1976 Classification of human colorectal adenocarcinoma cell lines. Cancer Research 36 4562-4569.

Lim GE, Huang GJ, Flora N, LeRoith D, Rhodes CJ \& Brubaker PL 2009 Insulin regulates glucagon-like peptide- 1 secretion from the enteroendocrine L cell. Endocrinology 150 580-591. (https://doi. org/10.1210/en.2008-0726)

Liu C, Chen J, Sutton S, Roland B, Kuei C, Farmer N, Sillard R \& Lovenberg TW 2003 Identification of relaxin-3/INSL7 as a ligand for 
GPCR142. Journal of Biological Chemistry 278 50765-50770. (https:// doi.org/10.1074/jbc.M308996200)

Liu C, Kuei C, Sutton S, Chen J, Bonaventure P, Wu J, Nepomuceno D, Kamme F, Tran D-T, Zhu J, et al. 2005 INSL5 is a high affinity specific agonist for GPCR142 (GPR100). Journal of Biological Chemistry 280 292-300. (https://doi.org/10.1074/jbc.M409916200)

Luo X, Li T, Zhu Y, Dai Y, Zhao J, Guo Z-Y \& Wang M-W 2015 The insulinotrophic effect of insulin-like peptide 5 in vitro and in vivo. Biochemical Journal 466 467-473. (https://doi.org/10.1042/ BJ20141113)

MacDonald PE, El-Kholy W, Riedel MJ, Salapatek AMF, Light PE \& Wheeler MB 2002 The multiple actions of GLP-1 on the process of glucose-stimulated insulin secretion. Diabetes 51 (Supplement 3) S434-S442. (https://doi.org/10.2337/diabetes.51.2007.S434)

Manning BD \& Cantley LC 2007 AKT/PKB signaling: navigating downstream. Cell 129 1261-1274. (https://doi.org/10.1016/j. cell.2007.06.009)

Mashima H, Ohno H, Yamada Y, Sakai T \& Ohnishi H 2013 INSL5 may be a unique marker of colorectal endocrine cells and neuroendocrine tumors. Biochemical and Biophysical Research Communications 432 586-592. (https://doi.org/10.1016/j.bbrc.2013.02.042)

Mouradov D, Sloggett C, Jorissen RN, Love CG, Li S, Burgess AW, Arango D, Strausberg RL, Buchanan D, Wormald S, et al. 2014 Colorectal cancer cell lines are representative models of the main molecular subtypes of primary cancer. Cancer Research 74 3238-3247. (https://doi.org/10.1158/0008-5472.CAN-14-0013)

Munro J, Skrobot O, Sanyoura M, Kay V, Susce MT, Glaser PEA, de Leon J, Blakemore AIF \& Arranz MJ 2012 Relaxin polymorphisms associated with metabolic disturbance in patients treated with antipsychotics. Journal of Psychopharmacology 26 374-379. (https:// doi.org/10.1177/0269881111408965)

Nica AC, Ongen H, Irminger J-C, Bosco D, Berney T, Antonarakis SE, Halban PA \& Dermitzakis ET 2013 Cell-type, allelic, and genetic signatures in the human pancreatic beta cell transcriptome. Genome Research 23 1554-1562. (https://doi.org/10.1101/ gr.150706.112)

Ørskov C, Wettergren A \& Holst JJ 1996 Secretion of the incretin hormones glucagon-like peptide- 1 and gastric inhibitory polypeptide correlates with insulin secretion in normal man throughout the day. Scandinavian Journal of Gastroenterology 31 665-670. (https://doi. org/10.3109/00365529609009147)

Park J-G, Oie HK, Sugarbaker PH, Henslee JG, Chen T-R, Johnson BE \& Gazdar A 1987 Characteristics of cell lines established from human colorectal carcinoma. Cancer Research 47 6710-6718.

Parker HE, Adriaenssens A, Rogers G, Richards P, Koepsell H, Reimann F \& Gribble FM 2012 Predominant role of active versus facilitative glucose transport for glucagon-like peptide-1 secretion. Diabetologia 55 2445-2455. (https://doi.org/10.1007/s00125-012-2585-2)

Pinto AT, Pinto ML, Velho S, Pinto MT, Cardoso AP, Figueira R, Monteiro A, Marques M, Seruca R, Barbosa MA, et al. 2016 Intricate macrophage-colorectal cancer cell communication in response to radiation. PLOS ONE 11 e0160891. (https://doi.org/10.1371/journal. pone.0160891)

Psichas A, Glass LL, Sharp SJ, Reimann F \& Gribble FM 2016 Galanin inhibits GLP-1 and GIP secretion via the GAL1 receptor in enteroendocrine L and K cells. British Journal of Pharmacology 173 888-898. (https://doi.org/10.1111/bph.13407)

Reimann F, Ward PS, \& Gribble FM 2006 Signaling mechanisms underlying the release of glucagon-like peptide 1. Diabetes 55 S78S85. (https://doi.org/10.2337/db06-S010)
Reimann F, Habib AM, Tolhurst G, Parker HE, Rogers GJ \& Gribble FM 2008 Glucose sensing in L cells: a primary cell study. Cell Metabolism 8 532-539. (https://doi.org/10.1016/j.cmet.2008.11.002)

Reimann F, Tolhurst G \& Gribble FM 2012 G-protein-coupled receptors in intestinal chemosensation. Cell Metabolism 15 421-431. (https:// doi.org/10.1016/j.cmet.2011.12.019)

Reimer RA, Darimont C, Gremlich S, Nicolas-Métral V, Rüegg UT \& Macé K 2001 A human cellular model for studying the regulation of glucagon-like peptide-1 secretion. Endocrinology $1424522-4528$. (https://doi.org/10.1210/endo.142.10.8415)

Ruvinsky I \& Meyuhas O 2006 Ribosomal protein S6 phosphorylation: from protein synthesis to cell size. Trends in Biochemical Sciences $\mathbf{3 1}$ 342-348. (https://doi.org/10.1016/j.tibs.2006.04.003)

Sheng YH, Triyana S, Wang R, Das I, Gerloff K, Florin TH, Sutton P \& McGuckin MA 2013 MUC1 and MUC13 differentially regulate epithelial inflammation in response to inflammatory and infectious stimuli. Mucosal Immunology 6 557-568. (https://doi.org/10.1038/ mi.2012.98)

Sheng YH, He Y, Hasnain SZ, Wang R, Tong H, Clarke DT, Lourie R, Oancea I, Wong KY, Lumley JW, et al. 2017 MUC13 protects colorectal cancer cells from death by activating the NF- $\mathrm{B}$ pathway and is a potential therapeutic target. Oncogene 36 700-713. (https:// doi.org/10.1038/onc.2016.241)

Singh A, Sweeney MF, Yu M, Burger A, Greninger P, Benes C, Haber DA \& Settleman J 2012 TAK1 inhibition promotes apoptosis in KRASdependent colon cancers. Cell 148 639-650. (https://doi. org/10.1016/j.cell.2011.12.033)

Suardet L, Gaide AC, Calmès JM, Sordat B, Givel JC, Eliason JF \& Odartchenko N 1992 Responsiveness of three newly established human colorectal cancer cell lines to transforming growth factors beta 1 and beta 2. Cancer Research 52 3705-3712.

Thanasupawat T, Hammje K, Adham I, Ghia J-E, Del Bigio MR, Krcek J, Hoang-Vu C, Klonisch T \& Hombach-Klonisch S 2013 INSL5 is a novel marker for human enteroendocrine cells of the large intestine and neuroendocrine tumours. Oncology Reports 29 149-154. (https:// doi.org/10.3892/or.2012.2119)

Trabelsi MS, Daoudi M, Prawitt J \& Ducastel S 2015 Farnesoid X receptor inhibits glucagon-like peptide-1 production by enteroendocrine $\mathrm{L}$ cells. Nature 6 7629. (https://doi.org/10.1038/ncomms8629)

Turjanski AG, Vaque JP \& Gutkind JS 2007 MAP kinases and the control of nuclear events. Oncogene 26 3240-3253. (https://doi.org/10.1038/ sj.onc.1210415)

Uhlén M, Fagerberg L, Hallström BM, Lindskog C, Oksvold P, Mardinoglu A, Sivertsson Å, Kampf C, Sjöstedt E, Asplund A, et al. 2015 Proteomics. Tissue-based map of the human proteome. Science347 1260419. (https://doi.org/10.1126/science.1260419)

Watts VJ, Taussig R, Neve RL \& Neve KA 2001 Dopamine D2 receptorinduced heterologous sensitization of adenylyl cyclase requires Gas: characterization of Gos-insensitive mutants of adenylyl cyclase V. Molecular Pharmacology 60 1168-1172. (https://doi.org/10.1124/ mol.60.6.1168)

Yue F, Cheng Y, Breschi A, Vierstra J, Wu W, Ryba T, Sandstrom R, Ma Z, Davis C, Pope BD, et al. 2014 A comparative encyclopedia of DNA elements in the mouse genome. Nature 515 355-364. (https://doi. org/10.1038/nature13992)

Zhang L, Tetrault J, Wang W, Loh HH \& Law P-Y 2006 Short- and longterm regulation of adenylyl cyclase activity by $\delta$-opioid receptor are mediated by Goi2 in neuroblastoma N2A cells. Molecular Pharmacology 69 1810-1819. (https://doi.org/10.1124/ mol.105.021352)

Received in final form 2 January 2018

Accepted 17 January 2018 http://jme.endocrinology-journals.org https://doi.org/10.1530/JME-17-0152
๑) 2018 Society for Endocrinology Published by Bioscientifica Ltd. Printed in Great Britain 